\title{
Analisis Kinerja Bank Pembiayaan Rakyat Syariah (Bprs) \\ Di Provinsi Bengkulu Dengan Pendekatan Sharia Maqasid Index (Smi)
}

\author{
Nonie Afrianty \\ IAIN Bengkulu, Indonesia \\ Email : noni@iainbengkulu.ac.id
}

\begin{abstract}
This study aims to analyze the performance of the BPRS by looking at how much the level of achievement maslahah (welfare) in the sharia maqasid as well as comparing the performance among Islamic People's Financing Banks (BPRS) in Bengkulu Province with the Sharia Maqasid Index (SMI) approach. This research is a quantitative research with a descriptive approach. The population of this study is BPRS in Bengkulu Province which was recorded during the period March 2016 to March 2017. The sampling technique in this study was conduced by purposive sampling. The results of this study is BRRS Safir har superior performance with a value of 16,35\% while BPRS Muamalat Harkat with a value of 15,64\%. This show that BPRS Safir is a sharia banking institution that is not only profir oriented but there us education, justice and community welfare values that reflect the size of the non-profit benefits in accordance with the objectives of Islamic banks.
\end{abstract}

Keyword : Performance, BPRS, Sharia Maqasid Index

Abstrak : Penelitian ini bertujuan untuk menganalisis kinerja BPRS dengan melihat seberapa besar tingkat pencapaian maslahah (kesejateraan) dalam maqasid syariah serta membandingkan kinerja antar Bank Pembiayaan Rakyat Syariah (BPRS) di Provinsi Bengkulu dengan pendekatan Sharia Maqasid Index (SMI). Penelitian ini merupakan penelitian kuantitatif dengan pendekatan deskriptif. Populasi penelitian ini adalah BPRS di Provinsi Bengkulu yang tercatat selama periode Maret 2016 hingga Maret 2017. Teknik pengambilan sampel dalam penelitian ini dilakukan secara purposive sampling. Hasil penelitian ini menunjukkan bahwa BPRS Safir memiliki kinerja lebih unggul dengan nilai 16,35\% sedangkan BPRS Muamalat Harkat dengan nilai 15,64\%. Hal ini menunjukkan bahwa BPRS Safir merupakan lembaga keyangan syariah yang tidak hanya berorientasi pada keuntungan (laba) akan tetapi terdapat nilai pendidikan, keadilan dan kesejahteraan masyarakat yang mencerminkan ukuran manfaat non profit yang sesuai dengan tujuan bank syariah.

Kata Kunci : Kinerja, BPRS, Sharia Maqasid Index

\section{PENDAHULUAN}

Ekonomi Islam saat ini tengah disorot oleh banyak ekonom. Banyak yang beranggapan bahwa ekonomi Islam adalah solusi mutakhir untuk kebaikan bersama terhadap masyarakat pada umumnya dan para ekonom khususnya. Salah satu sektor yang memiliki peran penting dalam kemajuan ekonomi Islam adalah sektor perbankan. Sektor ini adalah sebuah instrumen penting yang berkontribusi terhadap kemajuan ekonomi Islam itu sendiri. Pada dasarnya perbankan syariah memiliki tujuan-tujuan yang dapat dihitung 
(dikualifikasi) dengan pendekatan yang benar. Sebagai hasilnya, tujuan dari perbankan syariah bisa diukur, didefinisikan, diperasikan dan berkontribusi kepada tujuan khusus atau umum. ${ }^{1}$

Perbankan syariah memiliki tujuan yang berbeda-beda antara satu dengan yang lainnya tergantung dari jenisnya. Berdasarkan Undang-Undang RI No. 7 Tahun 1992 tentang perbankan yang kemudian diperbaharui menjadi UndangUndang RI No.10 Tahun 1998. Menurut Undang-Undang tersebut keberadaan Bank Syariah telah diakui secara formal dan terdapat dua jenis bank syariah di Indonesia yaitu Bank Umum Syariah (BUS) dan Bank Pembiayaan Rakyat Syariah (BPRS). Perkembangan antara kedua jenis bank tersebut juga berbeda, Bank Umum Syariah (BUS) kedudukannya lebih populer dibandingkan dengan BPRS. Hal ini jelas berbeda salah satunya dilihat dari segmentasi masing-masing lembaga keuangan, kurang populernya BPRS dikarenakan alasan bahwa BPRS memiliki pembatasan kegiatan.

\section{Menurut} pembatasan kegiatan BPRS diantaranya adalah BPRS dilarang untuk melakukan kegiatan usaha yang dapat dilakukan oleh

${ }^{1}$ Thuba Jazil dan Syahruddin, "The Perfomance Measures of Selected Malaysia and Indonesian Islamic Banks Based on the Maqasid al-Shari'ah Approach", Jurnal Hukum dan Ekonomi:Ijtihad, Vol.7, No.2, 2013, hlm. 284
BUS seperti menerima simpanan berupa giro dan ikut serta dalam lalu lintas pembayaran. BPRS juga dilarang melakkan kegiatan usaha dalam valuta asing dan penyertaan modal. Namun pembatasan tersebut tidak serta merta membuat BPRS tersingkir dalam persaingan dengan BUS, keberadaan BPRS ditengah-tengah dominasi BUS sangat diperlukan dan sebagai solusi karena memiliki market standing yang kuat di pasar khusus untuk meningkatkan produktivitas pada sektor riil, khususnya bagi usaha-usaha mikro, kecil dan menengah. Sehingga diharapkan dengan adanya BPRS di tengah-tengah masyarakat dapat tercapai pertumbuhan yang merata dalam perekonomian suatu negara. ${ }^{2}$

Berdasarkan

PBI

No.11/23/PBI/2009 tentang Bank Pembiayaan Syariah, keberadaan BPRS Syariah dimaksudkan untuk dapat memberikan layanan perbankan secara cepat, mudah dan sederhana kepada masyarakat khususnya pengusaha menengah, kecil dan mikro baik di perdesaan maupun diperkotaan yang selama ini belum terjangkau oleh layanan bank umum. Secara umum BPRS memiliki tujuan utama yang harus dicapai sekaligus, yaitu komersial dan pengembangan

\footnotetext{
${ }^{2}$ Veithzal Rivai, Basri M, Permata V.A, dan Tatik M, Financial Institution Management (MAnajemen Kelembagaan Keuangan), (Jakarta: PT. Raja Grafindo Persada, 2013), hlm. 697
} 
masyarakat. Komersial artinya BPRS dalam menjalankan usahanya harus memperoleh keuntungan agar aktiva dapat terjaga (sustainable) dan kemampuan melayani nasabah semakin meningkat (outreach). ${ }^{3}$

Untuk dapat tetap menjalankan perannya dengan baik, maka BPRS harus selalu meningkatkan kinerjanya sehingga dapat memperoleh kepercayaan dari pemilik dana dan dapat menyalurkannya untuk membantu produktivitas usaha mikro, kecil dan menengah sehingga dapat meningkatkan pembangunan nasional. Salah satu upaya yang dapat dilakukan untuk meningkatkan kinerja BPRS di Indonesia adalah dengan melakukan penilaian atau pengukuran kinerja BPRS.

Penerapan model evaluasi atau penilaian kinerja yang berkembang sekarang bisa dibilang copy paste model evaluasi kinerja yang digunakan oleh industri perbankan konvensional. Hal tersebut didukung dengan masing digunakannya sistem penilaian kinerja yang lebih berfokus kepada peran bank syariah sebagai organisasi bisnis, diantaranya: penilaian kinerja keuangan tradisional, balanced Scorecard (BSC) dan Capital, Asset Quality, Management, Earnings, Liquidity and Sensitivity to Market Risk
(CAMELS). Pengukuran kinerja yang dterapkan juga masih menggunakan pengukuran kinerja klasik yang sangat terfokus pada aspek keuangan seperti return on asset (ROA) dan return on equity (ROE), serta aspek teknisnya seperti biaya operasi dibagi pendapatan operasional (BOPO), nonperfoming financing (NPF) dan financing to deposits ratio (FDR), termasuk pengukuran efisiensi, seperti efisiensi teknis dan efisiensi biaya. Penggunaan ukuran kinerja keuangan dan teknis operasional oleh LKS mendorong LKS untuk lebih memperhatikan aspekaspek keuangan dan operasional saja, sedangkan aspek lainnya kurang mendapat perhatian yang memadai. ${ }^{4}$

Pada sisi teknis perbankan syariah memiliki kesamaan dengan perbankan konvensional. Akan tetapi perbankan syariah memiliki tujuan yang lebih luas dibandingkan perbankan konvensional, yaitu falah oriented dan komitmen spiritual dalam berbisnis. Perbankan syariah tidak hanya dituntut untuk mencari keuntungan belaka (high profitability), tetapi juga harus menjalankan fungsi dan tujuannya sebagai sebuah entitas syariah yang dilandaskan kepada konsep maqasid syariah (good

${ }^{3}$ Bank Indonesia, Peraturan Bank Indonesia No. 11/23/PBI/2009-Bank Pembiayaan Rakyat Syariah, http://www.bi.go.id/id/peraturan/perbankan/pages/pbi_1 12309.aspx, diakses tanggal 20 Maret 2017
${ }^{4}$ Ascarya, "Membuat Indeks Kinerja LKS Berdasarkan Tujuan Syariah”, Jurnal Ekonomi Islam Republika Iqtishodia, 2014, hlm. 25 
sharia objectives $)^{5}$. Oleh karena itu, perlu pergeseran paradigma dalam hal pengukuran kinerja perbankan syariah yang tidak hanya terbatas pada rasio keuangan akan tetapi harus bebas dari riba (bunga), bebas dari maysir (permainan kesempatan atau spekulasi) dan bebas dari gharar (ketidakpastian yang berlebihan) dalam semua operasinya.

\section{Berdasarkan Data Statistik}

Perbankan Syariah Juni 2016 terdapat 165 BPRS di Indonesia dan 2 diantaranya berada di Provinsi Bengkulu, yaitu BPRS Safir dan BPRS Muamalat Harkat.

Berdasarkan latar belakang di atas, penulis merasa perlu melakukan penelitian dengan menganalisis kinerja BPRS dengan melihat seberapa besar tingkat pencapaian maslahah (kesejateraan) dalam maqasid syariah jika ditinjau dari ketiga aspek, yang meliputi: pendidikan, penciptaan keadilan dan pencapaian kesejahteraan pada BPRS. Maka dapat dirumuskan permasalahan sebagai berikut:

1. Bagaimana kinerja Bank Pembiayaan Rakyat Syariah (BPRS) di Provinsi Bengkulu dengan Pendekatan Sharia Maqasid Index (SMI) Periode Kuartal Maret 2016 - Maret 2017?
2. Bagaimana perbandingan pengukuran kinerja antar Bank Pembiayaan Rakyat Syariah (BPRS) di Provinsi Bengkulu dengan pendekatan Sharia Maqasid Index (SMI) Periode Kuartal Maret 2016 - Maret 2017?

\section{METODE PENELITIAN}

Penelitian ini merupakan penelitian kuantitatif dengan pendekatan deskriptif. Pada penelitian ini proses analisis data yang dikerjakan pada umumnya ditujukan untuk menggambarkan kejadian-kejadian, ataupun hubungan variabel yang diamati saja. ${ }^{6}$ Metode kuantitatif yang digunakan pada penelitian ini menggunakan metode angka indeks (index number). ${ }^{7}$

Populasi penelitian ini adalah BPRS di Provinsi Bengkulu yang tercatat selama periode Maret 2016 hingga Maret 2017 dengan jumlah BPRS 2 BPRS. Teknik pengambilan sampel dalam penelitian ini dilakukan secara purposive sampling. Kriteria dalam pengambilan sampel adalah BPRS yang laporan keuangan tersedia secara lengkap selama lima kuartal dari kuartal maret 2016 sampai dengan maret 2017. Pemilihan sampel berdasarkan kelengkapan data yang dimiliki BPRS, terutama informasi mengenai Dana Pihak Ketiga (DPK), biaya operasional,

${ }^{6}$ Muhammad Teguh, Metode Kuantittatif untuk Indonesia ditinjau dari Maqasid Syariah : Pendekatan Syariah Maqasid Index (SMI) dan Profitabilitas Bank Syariah", Islamic Economic and Finance (IEF), Jakarta: Universitas Trisakti, 2012, hlm.-
Analisis EKonomi dan Bisnis, (Jakarta: Rajawali Pers, 2014), hlm. 21

${ }^{7}$ Ibid, hlm. 26 
pembiayaan yang disalurkan, aktiva lancar pendapatan operasional lainnya dan rasiorasio yang digunakan pada indikator Sharia Maqasid Index (SMI).

Data yang diperoleh merupakan data sekunder yang bersifat time series bersumber dari website resmi Bank Indonesia yaitu www.bi.go.id.

\section{HASIL DAN PEMBAHASAN KONSEP PENGUKURAN KINERJA}

Kinerja keuangan bank merupakan bagian dari kinerja bank secara keseluruhan. Secara keseluruhan kinerja (performance) bank merupakan gambaran prestasi yang dicapai bank dalam operasionalnya, meliputi aspek keuangan, pemasaran, penghimpunan dana, teknologi maupun sumber daya manusia. Dengan demikian kinerja keuangan bank merupakan gambaran kondisi keuangan bank pada suatu periode tertentu baik menyangkut aspek penghimpunan dana maupun penyaluran dana yang biasanya diukur dengan indikator kecukupan modal, likuiditas dan profitabilitas. $^{8}$

Sebagai wujud yang dicapai perusahaan dalam periode waktu usaha, tidak lepas dari kinerja yang dilakukan pihak bank. Apabila kinerja bank bagus, akan menghasilkan prestasi kerja yang bagus pula, begitu juga

\footnotetext{
${ }^{8}$ Edi Haryono, “Analisis Efisiensi Biaya Industri Perbankan Indonesia Dengan Menggunakan Metode Parametrik Scochastic Frontier Analysis", Tesis, Semarang: Universitas Diponegoro, 2009, hlm. 15
}

sebaliknya. Menurut Amin kinerja adalah hasil nyata yang dicapai, kadang-kadang dipergunakannya untuk menunjukkan dicapainya hasil yang positif. Kinerja bank dapat diketahui melalui penilaian tentang tingkat kesehatan bank, yang standarnya telah ditentukan oleh Bank Indonesia. ${ }^{9}$

Penilaian prestasi dan kondisi keuangan pada suatu perusahaan membutuhkan ukuranukuran tertentu, yang biasanya digunakan analisis rasio untuk menunjukkan antara dua data keuangan. Rasio-rasio keuangan ini harus dihubungkan dengan beberapa standar, salah satunya melalui pola historia perusahaan untuk sejumlah tahun dalam menentukan perusahaan membaik atau memburuk. ${ }^{10}$

Kinerja menunjukkan sesuatu yang berhubungan dengan kekuatan dan kelemahan perusahaan. Kekuatan tersebut dipahami agar dapat dimanfaatkan dan kelemahanpun harus diketahui agar dapat dilakukan langkahlangkah perbaikan. Dengan mengadakan perbandingan kinerja perusahaan terhadap standa yang ditetapkan atau dengan priodeperiode sebelumnya maka akan dapat diketahui apakah suatu perusahaan mencapai kemajuan atau sebaliknya yaitu mengalami kemunduran. ${ }^{11}$

Berdasarkan pengukuran kerja di atas bahwa untuk menilai kesehatan suatu perusahaan atau organisasi membutuhkan

\footnotetext{
${ }^{9}$ Ibid, hlm. 15

${ }^{10}$ Ibid, hlm. 15-16

${ }^{11}$ Ibid, hlm. 16
} 
beberapa penilaian yang data diwakili melalui pengukuran kinerja. Pengukuran kinerja merupakan bagian dari sistem pengendalian manajemen yang mencakup tindakan menyiratkan keputusan perencanaan, penilaian kinerja dan operasi karyawan. Penilaian kinerja adalah alat manajemen untuk menentukan seberapa jauh adalah tujuan perusahaan yang telah dicapai, mengevaluasi kinerja bisnis, manajer, divisi dan individu dalam perusahaan, juga untuk memprediksi harapan perusahaan di masa depan. Kinerja yang unggul ditandai dengan efektif dan efisien pekerjaan dengan baik. Sistem pengukuran kinerja yang handal merupakan salah satu faktor kunci keberhasilan organisasi. Informasi yang digunakan untuk mengambil pengukuran kinerja atau penilaian kinerja dikelompokkan menjadi dua kategori: ${ }^{12}$

\section{a. Kinerja Keuangan}

Kinerja keuangan adalah suatu analisis yang dilakukan untuk melihat sejauh mana suatu perusahaan telah melaksanakan dengan menggunakan aturan-aturan pelaksanaan keuangan secara baik dan benar. ${ }^{13}$ Pengukuran laporan keuangan dinilai berdasarkan anggaran yang telah dibuat. Pengukuran dilakukan dengan menganalisis varians antara kinerja aktual dan anggaran. Analisis varian sebagian besar difokuskan pada dua varian, yaitu:

\footnotetext{
${ }^{12}$ M. Syafi'I Antonio, dkk., “An Analysis of... hlm. 13-14

${ }^{13}$ Irham Fahmi, Analisis Kinerja Keuangan: Panduan Bagi Akademisi, Manajer dan Investor Untuk Menilai dan Menganalisis Bisnis Dari Aspek Keuangan, (Bandung: Alfabeta, 2012), hlm. 2
}

varian pendapatan dan varian pengeluaran yang mencakup pengeluaran rutin dan investasi/modal.

Menurut Kasmir, dalam system perbankan untuk menentukan kondisi atau kinerja suatu bank biasanya menggunakan analisis CAMELS (Capital, Asset, Management, Earning, Liquidity, Sensitivity Risiko). Pengukuran dan evaluasi model ini telah dinyatakan oleh Bank Indonesia agar bankbank di Indonesia diwajibkan untuk membuat laporan rutin dan teratur.

Seiring dengan perkembangan alat evaluasi untuk mengatur kinerja perusahaan termasuk industry perbankan, muncul alat evaluasi yang disebut dengan Economic Value Added (EVA). EVA adalah nilai tambah yang diberikan oleh manajemen kepada pemegang saham untuk tahun tertentu.

b. Informasi Non-Keuangan

Informasi non-keuangan bisa menjadi patokan lain. Informasi non-keuangan dapat meningkatkan kepercayaan dalam kualitas kontrol pada proses manajemen. Teknik pengukuran kinerja yang komprehensif yang telah dikembangkan oleh berbagai organisasi adalah Balance Scorecard yang terdiri dari empat aspek, diantaranya: perspektif keuangan, kepuasan pelanggan, efisiensi proses internal dan pembelajaran dan pertumbuhan keuangan.

Proses pengukuran kinerja perusahaan pada umumnya menggunakan rasio. Namun, penggunaan patokan keuangan sebagai satu- 
satunya ukuran kinerja perusahaan memiliki banyak kelemahan, diantaranya: Penggunaan kinerja keuangan sebagai satusatunya ukuran kinerja perusahaan dapat mendorong manajer untuk mengambil tindakan jangka pendek dan mengabaikan rencana jangka panjang; (2) Mengabaikan aspek pengukuran non keuangan dan aset tidak berwujud, baik dari internal maupun eksternal akan memberikan pandangan keliru dari para manajer perusahaan di masa sekarang bahkan masa yang akan dating; dan (3) Kinerja keuangan yang hanya didasarkan pada kinerja masa lalu kurang mampu membawa perusahaan terhadap tujuan perusahaan. ${ }^{14}$

Penilaian kinerja dimanfaatkan oleh manajemen untuk mengelola operasi organisasi secara efektif dan efisien melalui permotivasi karyawan secara maksimum;Membantu pengambilan keputusan yang bersangkutan dengan karyawan seperti promosi, pemberhentian dan mutasi;Mengidentifikasi kebutuhan pelatihan dan pengembangan karyawan dan untuk menyediakan kriteria seleksi dan evaluasi program pelatihan karyawan.;Menyediakan umpan balik bagi karyawan mengenai bagaimana atasan mereka menilai kinerja

\footnotetext{
${ }^{14}$ M. Syafi'I Antonio, dkk., “An Analysis of..., hlm. 14
}

mereka;Menyediakan suatu dasar bagi distribusi penghargaan. ${ }^{15}$

Adapun tujuan atau manfaat pengukuran kinerja adalah Untuk mengetahui tingkat likuiditas, yaitu kemampuan perusahaan untuk memenuhi kewajiban keuangannya pada saat ditagih;Untuk mengetahui solvabilitas, yaitu kemampuan perusahaan untuk memenuhi kewajiban keuangannya apabila perusahaan tersebut likuiditas baik kewajiban keuangannya apabila perusahaan tersebut likuiditas baik kewajiban keuangan jangka pendek maupun jangka panjang;Untuk mengetahui tingkat rentabilitas (profitability), yaitu menunjukkan kemampuan perusahaan menghasilkan laba selama periode tertentu. ${ }^{16}$

\section{KINERJA MAQASID SYARIAH BPRS}

Rasio kinerja maqasid syariah setiap BPRS merupakan ukuran untuk menentukan bagaimana bank melaksanakan tujuan-tujuan syariah yang telah ditentukan. Untuk mengetahui sejauh mana BPRS melaksanakan setiap tujuan-tujuan maqasid syari'ah dapat diukur melalui rasio kinerja maqasid syari'ah yang telah dibagi menjadi tiga tujuan yaitu Mendidik individu (Tahzib alfardhu); Menegakkan keadilan (Iqomat aladl);Kemaslahatan (Jaib al-maslahah).

\footnotetext{
${ }^{15}$ Mulyadi, Akuntansi Manajemen: Konsep, Manfaat dan Rekayasa”, Edisi ke-3, (Yogyakarta: STIE YKPN, 2001), hlm. 416

${ }^{16}$ Indra Prasetyo, "Analisis Kinerja Keuangan Bank Syariah dan Bank Konvensional di Indonesia", Jurnal Aplikasi Manajemen, Vol. 6, No. 2, 2008, hlm. 166
} 
Berdasarkan rasio kinerja maqasid syariah dari BPRS Safir dan BPRS Muamalat Harkat untuk Tujuan 1, Tujuan 2 dan Tujuan 3 menghasilkan BPRS yang memiliki nilai tertinggi pada setiap rasionya yang dalam hal ini menunjukkan kemampuan perusahaan dalam melaksanakan fungsi syariahnya yang diukur melalui 10 rasio kinerja :

a. Tujuan Pertama : Mendidik Manusia (Tahzib al-fardhu)

Tujuan pertama maqasid syari'ah adalah mendidik manusia, terdapat tiga aspek pengukuran yang digunakan dalam mengukur sejauh mana BPRS melaksanakan tujuannya dalam mendidik manusia, antara lain: advancement knowledge, instilling new skill and improvement and creating awareness of Islamic banking. Berikut adalah tabel rasio kinerja maqasid syariah untuk tujuan pertama:

Tabel 1

Rasio Kinerja Maqasid Syariah Rata-Rata Tujuan Pertama Bank Pembiayaan Rakyat Syariah di Provinsi Bengkulu Periode Maret 2016-2017

\begin{tabular}{|l|c|c|}
\hline \multirow{2}{*}{ BPRS } & \multicolumn{2}{|c|}{ Rasio Kinerja Tujuan 1 } \\
\cline { 2 - 3 } & $\mathbf{R}_{\mathbf{1 1 , 3 1}}$ & $\mathbf{R}_{\mathbf{2 1 , 4 1}}$ \\
\hline Safir & 51,28 & 45,88 \\
\hline Harkat & 70,29 & 21,63 \\
\hline
\end{tabular}

Sumber: Data diolah 2017

Berdasarkan tabel $4.1 \mathrm{di}$ atas dapat diketahui bahwa untuk hibah pendidikan dan pelatihan (education grant dan training expense) ditunjukkan oleh $\quad \mathrm{R}_{11}, \mathrm{R}_{31}$ yang diperoleh dari beban personalia. Maka dapat diketahui bahwa BPRS Muamalat Harkat memiliki rasio yang lebih tinggi dengan nilai $70.29 \%$. Rasio ini menunjukkan tingginya kepedulian BPRS Muamalat Harkat terhadap pendidikan dan perkembangan karyawannya.

Rasio selanjutnya untuk penelitian dan publikasi (research expense dan publicity expense) ditunjukkan oleh $\mathrm{R}_{21}, \mathrm{R}_{41}$ diperoleh dari beban administrasi dan umum. Maka dapat diketahui bahwa BPRS Safir memiliki rasio yang lebih tinggi dengan nilai 45,88\%. Hal ini menunjukkan bahwa tingginya kepedulian BPRS Safir dalam memberikan informasi kepada masyarakat atau pemangku kepentingan mengenai produk syariah.

b. Tujuan Kedua : Menegakkan Keadilan (Iqomat al-adl)

Pada tujuan kedua maqasid syari'ah ini ada tiga rasio pengukuran yang digunakan dalam mengukur sejauh mana BPRS melaksanakan tujuannya dalam menegakkan keadilan dalam rangka komitmen bank untuk menegakkan keadilan ekonomi dan tercipta hubungan yang saling menguntungkan antara bank dengan masyarakat, antara lain: fair returns, cheap products and services dan elimination injustice. Berikut adalah tabel 
rasio kinerja maqasid syariah untuk tujuan kedua:

Tabel 2

Rasio Kinerja Maqasid Syariah Rata-Rata Tujuan Kedua Bank Pembiayaan Rakyat Syariah di Provinsi Bengkulu Periode Maret 2016-2017

\begin{tabular}{|l|c|c|c|}
\hline \multirow{2}{*}{ BPRS } & \multicolumn{3}{|c|}{ Rasio Kinerja Tujuan 1 } \\
\cline { 2 - 4 } & $\mathbf{R}_{\mathbf{1 2}}$ & $\mathbf{R}_{\mathbf{2 2}}$ & $\mathbf{R}_{\mathbf{3 2}}$ \\
\hline Safir & 0 & 5,41 & 4,57 \\
\hline Harkat & 0 & 0 & 7,26 \\
\hline
\end{tabular}

Sumber: Data diolah 2017

Berdasarkan Dari tabel 4.2 di atas pada rasio $R_{12}$ yang merupakan rasio pertama tujuan ke-2 yaitu fair return tidak dapat dihitung, karena ukuran yang digunakan untuk menghitung rasio ini menggunakan rasio Profit Equalization Reserve (PER), seperti yang diketahui bahwa BPRS tidak melaporkan alokasi dana untuk PER pada laporan keuangannya. Hal ini dilakukan karena apabila BPRS menempatkan sebagian penetapannya untuk PER maka bank dianggap memungkiri hak deposan atas keuntungannya.

Rasio kedua tujuan kedua yang ditunjukkan oleh $\mathrm{R}_{22}$ yaitu rasio functional distribution, hasil perhitungan rasio kedua ini dihitung dari rasio pembiayaan dengan skim bagi hasil (mudharabah dan musyarakah) terhadap skim lainnya menunjukkan bahwa BPRS Safir memiliki nilai yang lebih tinggi dengan nilai sebesar $5,41 \%$ sedangkan BPRS
Muamalat Harkat tidak menyalurkan dananya pada pembiayaan dengan skim bagi hasil (mudharabah dan musyarakah). Hal ini menunjukkan bahwa BPRS Safir dianggap lebih mencerminkan keadilan dikarenakan BPRS turut merasakan kondisi di sector riil apakah untuk atau rugi. Skim bagi hasil juga mencerminkan hubungan kemitraaan jangka panjang yang mengandalkan kepercayaan.

Rasio ketiga tujuan kedua ditunjukkan oleh $\mathrm{R}_{32}$ yaitu rasio interest free income yang dicerminkan melalui rasio pendapatan bebas bunga dibandingkan dengan total pendapatan. Pada rasio ketiga ini menunjukkan bahwa BPRS di Provinsi Bengkulu masih menjalankan aktivitas yang mengandung riba. BPRS yang paling mendekati dari transaksi yang bebas riba atau yang memperoleh nilai tertinggi adalah BPRS Muamalat Harkat dengan rasio 7,26\%. Riba (suku bunga) merupakan salah satu instrumen yang dilarang dalam sistem perbankan dan keuangan syariah. Hal ini disebabkan karena riba memberikan dampak buruk terhadap perekonomian dan menyebabkan ketidakadilan dalam transaksi ekonomi. Sehingga sebagai lembaga keuangan yanng didasarkan pada syariat Islam, BPRS dituntut untuk menjalankan aktivitas perbankan yang 
dilakukan adalah aktivitas yang terbebas dari riba.

c. Tujuan Ketiga : Kemaslahatan (Jaib almaslahah)

Pada tujuan ketiga maqasid syari'ah ini ada tiga rasio pengukuran yang digunakan dalam mengukur sejauh mana BPRS melaksanakan tujuannya dalam mewujudkan kemaslahatan umat, antara lain: profit Ratios, personal income dan investement ratios in real sectors. Berikut adalah tabel rasio kinerja maqasid syariah untuk tujuan ketiga:

Tabel 3

Rasio Kinerja Maqasid Syariah Rata-Rata Tujuan Kedua Bank Pembiayaan Rakyat Syariah di Provinsi Bengkulu Periode Maret 2016-2017

\begin{tabular}{|l|l|c|c|}
\hline \multirow{2}{*}{ BPRS } & \multicolumn{3}{|c|}{ Rasio Kinerja Tujuan 1 } \\
\cline { 2 - 4 } & $\mathbf{R}_{\mathbf{1 3}}$ & $\mathbf{R}_{\mathbf{2 3}}$ & $\mathbf{R}_{\mathbf{3 3}}$ \\
\hline Safir & 3,76 & 0 & 0 \\
\hline Harkat & 7,53 & 0 & 0 \\
\hline
\end{tabular}

Sumber: Data diolah 2017

Berdasarkan tabel 4.3 di atas pada rasio $\mathrm{R}_{13}$ yang merupakan rasio pertama tujuan ketiga hasil perhitungan rasio kedua ini dihitung dari pendapatan bersih terhadap total aktiva (net incomel total asset) menunjukkan bahwa BPRS Muamalat Harkat memperoleh nilai lebih tinggi yaitu dengan nilai 7,53\% sedangkan BPRS Safir memperoleh nilai 3,76\%. Hal ini menunjukkan bahwa BPRS Muamalat Harkat memiliki kemampuan aset yang dikelola dengan baik sehingga menghasilkan pendapatan bersih sebesar $7,53 \%$ dari total aset. BPRS yang memiliki kemampuan untuk mengelola kekayaan dengan baik secara optimal dan bijaksana dengan tujuan untuk memperoleh laba yang tinggi merupakan salah satu perwujudan dari hifzul maal (penjagaan terhadap harta). Perolehan laba yang maksimal dapat memungkinkan BPRS berkontribusi lebih terhadap pajak untuk pembangunan negara serta memungkinkan berkontribusi yang lebih besar untuk kemaslahatan masyarakat.

Rasio kedua tujuan ketiga yang ditunjukkan oleh $\mathrm{R}_{23}$ yaitu rasio personal income, hasil perhitungan rasio kedua ini dihitung dari rasio zakat yang dikeluarkan oleh BPRS terhadap aset bersih (zakat paid/net asset) menunjukkan bahwa BPRS di Provinsi Bengkulu belum membayarkan zakatnya atau tidak mencatat zakatnya pada laporan keuangan secara detail.

Rasio ketiga tujuan ketiga yang ditunjukkan oleh $\mathrm{R}_{33}$ yaitu rasio investment in real sector, hasil perhitungan rasio ketiga ini dihitung dari rasio investasi yang dilakukan oleh BPRS di sektor riil dibandingkan dengan keseluruhan investasi yang dilakukan BPRS. Dalam rasio ini tidak dapat dihitung karena BPRS sebagai lembaga keuangan yang termasuk dalam lembaga keuangan mikro yang tidak melakukan investasi di sektor riil. 


\section{INDIKATOR KINERJA BPRS DI INDONESIA}

Setelah diketahui hasil perhitungan rasio kinerja maqashid syari'ah dari masing-masing BPRS, selanjutnya adalah menentukan peringkat kinerja maqasid syari'ah dari setiap BPRS. Proses tersebut dilakukan melalui Indikator Kinerja (IK) setiap BPRS. Proses tersebut menggunakan Simple Additive Weighting Method (SAW) dengan cara pembobotan, agregat dan proses menentukan peringkat (weighting, aggregating and rangking processes). Berikut ini adalah Indikator Kinerja Setiap BPRS berdasarkan tujuan-tujuan maqasid syari'ah diantaranya:

\section{Tabel 4}

Indikator Kinerja Maqasid Syariah Tujuan 1-3

BPRS Periode Maret 2016-2017

\begin{tabular}{|l|c|c|c|}
\hline \multirow{2}{*}{ BPRS } & \multicolumn{3}{|c|}{ Indikator Kinerja } \\
\cline { 2 - 4 } & IK (T1) & IK (T2) & $\begin{array}{c}\text { IK } \\
\text { (T3) }\end{array}$ \\
\hline Safir & 14,57 & 1,42 & 0,35 \\
\hline Muamalat & 13,78 & 1,13 & 0,72 \\
\hline
\end{tabular}

Sumber: Data diolah 2017

Berdasarkan tabel 4.4 di atas dapat diketahui bahwa indikator kinerja untuk tujuan pertama yang memperoleh indikator kinerja lebih tinggi adalah BPRS Safir dengan nilai indikator kinerja 14,57\%. Maka dengan ini menunjukkan bahwa BPRS Safir ikut serta berperan dalam merancang program pendidikan dan pelatihan dengan nilai-nilai moral sehingga mereka akan mampu meningkatkan kemampuan keahlian karyawan serta berperan dalam mengembangkan pengetahuan masyarakat.

Tujuan kedua yaitu menegakkan keadilan (Iqamah al-'adl), dari tabel 4.4 di atas dapat diketahui BPRS Safir juga memiliki nilai lebih tinggi sebesar 1,42. Maka dengan ini menunjukkan bahwa BPRS Safir dapat melakukan transaksi secara adil dalam sosial ekonomi melalui transaksi bagi hasil yang berakibat pada tidak merugikan nasabah.

Tujuan ketiga yaitu kemaslahatan, dari tabel 4.4 dapat dilihat bahwa BPRS Muamalat Harkat memiliki indikator kinerja yang lebih baik dari pada BPRS Safir dengan nilai indikator kinerja sebesar $0,72 \%$ hal ini masih jauh dari nilai baik. Dengan indikator kinerja tujuan ketiga ini menunjukkan bahwa BPRS mampu mewujudkan kemaslahatan yang tidak hanya dimiliki oleh pemilik dan pegawainya, tetapi berdampak pada semua golongan atau mampu mengembangkan proyek investasi dan pelayanan sosial untuk meningkatkan kemaslahatan masyarakat.

\section{SHARIA MAQASID INDEX (SMI) BPRS DI INDONESIA}

Sharia Maqasid Index (SMI) merupakan total dari semua indikator kinerja maqasid syari'ah BPRS untuk ketiga tujuan (tujuan 13), yaitu tujuan mendidik manusia, menciptakan keadilan dan menciptakan kemaslahatan. Berikut ini merupakan tabel yang menunjukkan nilai Sharia Maqasid Index 
(SMI) pada 2 BPRS di Provinsi Bengkulu periode Maret 2016-2017 :

Tabel 5

Sharia Maqasid Index (SMI) BPRS di Provinsi Bengkulu

Periode Maret 2016-2017

\begin{tabular}{|l|c|c|}
\hline \multicolumn{1}{|c|}{ BPRS } & SMI & PERINGKAT \\
\hline Safir & 16,35 & 1 \\
\hline Muamalat Harkat & 15,64 & 2 \\
\hline
\end{tabular}

Sumber: Data diolah 2017

Berdasarkan tabel 7 menunjukkan bahwa BPRS Safir memiliki kinerja lebih unggul dengan nilai $16,35 \%$ sedangkan BPRS Muamalat Harkat dengan nilai 15,64\%. Hal ini menunjukkan bahwa BPRS Safir merupakan lembaga keyangan syariah yang tidak hanya berorientasi pada keuntungan (laba) akan tetapi terdapat nilai pendidikan, keadilan dan kesejahteraan masyarakat yang mencerminkan ukuran manfaat non profit yang sesuai dengan tujuan bank syariah.

\section{KESIMPULAN}

Penelitian ini bertujuan untuk menganalisis kinerja BPRS dengan melihat seberapa besar tingkat pencapaian maslahah (kesejateraan) dalam maqasid syariah dengan menggunakan pendekatan Sharia Maqasid Index (SMI). Pengukuran kinerja merupakan salah satu cara evaluasi yang dapat digunakan untuk meningkatkan keberhasilan kinerja suatu perusahaan. Hasil pengukuran kinerja dengan pendekatan Sharia Maqasid Index (SMI) menghasilkan BPRS safir dengan nilai SMI sebesar $16,35 \%$.
Hasil penelitian ini juga menunjukkan bahwa BPRS memiliki kelebihan dan kekurangan pada setiap elemen-elemen maqasid syariah.

\section{DAFTAR PUSTAKA}

Aam Rusydiana, 2013, "Maqasid Syariah Index sebagai Ukuran Kinerja Perbankan", Jurnal Ekonomi Islam, Vol.3, No. 1, 2013

Afrinaldi, 2012, “Analisa Kinerja Perbankan Syariah Indonesia ditinjau dari Maqasid Syariah : Pendekatan Syariah Maqasid Index (SMI) dan Profitabilitas Bank Syariah", Islamic Economic and Finance (IEF), Jakarta: Universitas Trisakti

Antonio, Muhammad Syafii., dkk, 2012, “An Analysis of Islamic Banking Performance: Maqasid Index Implementation in Indonesia and Jordania", Jurnal of Islamic Finance, Vol.1, No.1 2012, IIUM Institute Of Islamic Banking and Finance"

Ascarya, 2014, "Membuat Indeks Kinerja LKS Berdasarkan Tujuan Syariah", Jurnal Ekonomi Islam Republika Iqtishodia

Bank Indonesia, Peraturan Bank Indonesia No. 11/23/PBI/2009-Bank Pembiayaan Rakyat Syariah, http://www.bi.go.id/id/peraturan/p erbankan/pages/pbi_112309.aspx, diakses tanggal 20 Maret 2017

Dzuljastri, Abdul Razak., Mustafa Omar Mohammed., 2008, "The Performance Measures of Islamic Banking Based on The Maqasid Framework", Best Paper, IIUM INTAC IV

Fahmi, Irham., 2012, Analisis Kinerja Keuangan: Panduan Bagi Akademisi, Manajer dan Investor 
Untuk Menilai dan Menganalisis Bisnis Dari Aspek Keuangan, Bandung: Alfabeta

Fauzia, Ika Yunia., Abdul Kadir Riyadi., 2014 Prinsip Dasar Ekonomi Islam Perspektif Maqasid al-Syariah, Jakarta: Kencana

Haryono, Edi., 2009, “Analisis Efisiensi Biaya Industri Perbankan Indonesia Dengan Menggunakan Metode Parametrik Scochastic Frontier Analysis", Tesis, Semarang: Universitas Diponegoro

Jazil, Thuba., Syahruddin. 2013, “The Perfomance Measures of Selected Malaysia and Indonesian Islamic Banks Based on the Maqasid alShari'ah Approach", Jurnal Hukum dan Ekonomi:Ijtihad, Vol.7, No.2, 2013

Mulyadi, 2001, Akuntansi Manajemen: Konsep, Manfaat dan Rekayasa", Edisi ke-3, Yogyakarta: STIE YKPN

Prasetyo, Indra., 2008, "Analisis Kinerja Keuangan Bank Syariah dan Bank Konvensional di Indonesia", Jurnal Aplikasi Manajemen, Vol. 6, No. 2, 2008

Rivai, Veithzal., dkk, 2013, Financial Institution Management (MAnajemen Kelembagaan Keuangan), Jakarta: PT. Raja Grafindo Persada

Teguh, Muhammad., 2014, Metode Kuantittatif untuk Analisis EKonomi dan Bisnis, (Jakarta: Rajawali Pers, 2014), hlm. 21 